\title{
Strach ze smrti u dospělých umírajících pacientů v terminální fázi onkologického onemocnění
}

\author{
Fear of Death in Adult Dying Patients in Terminal Stage \\ of Oncological Illness
}

\author{
Jaroslava Raudenská, Alena Javưrková
}

\begin{abstract}
Patients in terminal stage of oncological illness are situated in variety of phases of low sadness and also have to face to massive fear. The article describes in introduction process of dying a definition of death. Aims to terminal stage as moving to the death, which intervenes individual in whole existence. Describes approaches to fear of death, where individual approach of medical clinician to death can in extreme form be barrier in treatment of patients. The article for better understanding of fear of death differences anxiety, fear, phobia and thanotophobia. Adverts to the fact, that fear of death is not separate fear, but is always saturated by several types of fears. Only very few people absolutely accept or absolutely deny own death, oft is relationship ambivalent. That is why the article concerning also question, whether or not at all people wished to know they are dying and to what degree willingness of doctor to say patient he she is dying influents patient's coping with and control of own death. To all palliative medical team are set before not only high medical titles, but also titles to understanding of selves and own understanding of death, fear of death and its individual meaning. Thereafter every member of palliative team can better help by those experiences to the patients.
\end{abstract}

KEY WORDS fear of death, dying, terminal stage of oncological illness

\section{Úvod}

Součástí paliativní péče je péče medicínská, pečovatelská a péče pomáhajících psychosociálních profesí. Paliativní tým se proto skládá nejen z lékařů a zdravotních sester, ale také z dalších profesí, jako je např́iklad klinický psycholog, sociální či spirituální pracovník. Tým se zabývá lékařskou i nelékařskou péčí o nevyléčitelně nemocné $\mathrm{v}$ terminálním stadiu onkologické nemoci, které je konečnou fází lidského života a má existencionální dopad na nemocného i jeho okolí. Limity jsou tedy dány nejen lékařskou péćí v terminálním stavu (narozdíl od ostatních lékařských oborů, které léčí nebo částečně či zcela vracejí zdraví), ale také omezeností lidského života. Medicína sice s technickým pokrokem v současnosti zvyšuje terapeutické možnosti, ale v určitém okamžiku se dostává do situace, kdy její terapeutický potencionál klesne: nelze léčit nebo vyléčit. Nastupuje tlumení př́znaků, zajištění kvality této poslední fáze života nemocného, a především léčba utrpení a bolesti (Kozák 2002, Raudenská a Javưrková 2002). Tím medicína naráží na svůj limit současně s existenciálním

Sociální studia. Katedra sociologie FSS MU, 2/2011. S. 121-133. ISSN 1214-813X. 
omezením života. Tento fakt, někdy nevyřčený, může ovlivňovat duševní stav celého paliativního týmu, ale také duševní stav nemocného i jeho rodiny.

Pokud pacient trpí onemocněním ohrožující život, je to pro něho i jeho okolí potenciální katastrofa. Je konfrontován s pocitem vlastní smrtelnosti, což téměř pro každého znamená akutní, ale také chronický psychický stres. Psychické potíže souvisí se závažností, stádiem a formou léčby onkologického onemocnění. $V$ terminálním stadiu může negativně ovlivnit duševní stav medikace (napríklad steroidy), metabolické stavy (např́klad hyperkalcemie), metastázy centrálního nervového systému, hormony a ostatní faktory (Knight 2004). Také př́znaky nemoci, jako jsou bolest, dušnost, nauzea, zvracení, ztráta chuti k jídlu, ztráta mobility, slabost, včetně sekundárních přiznaků vyvolaných léčbou, mohou nejen ovlivnit, jakým způsobem proces umírání probíhá, ale i vyvolávat sekundární úzkost, bezmoc, skleslost, depresivní ladění, anticipační smutek ze ztráty a další. Psychické potíže ovlivňují i pacientovu schopnost se z něčeho těšit, zesilují intenzitu bolesti, snižují pacientovu schopnost emočně se rozloučit a říci sbohem.

\section{Definice smrti a procesu umírání}

Pojem „smrt“ se v přeneseném a širším významu užívá pro zánik kultury, politického systému, živočišného druhu apod. Smrt v užším smyslu je možné definovat z mnoha pohledů jednotlivých vědeckých disciplín: biologie, medicíny, psychologie, práva, filozofie a dalších. Věda zabývající se umíráním a smrtí se nazývá thanatologie. Slovo „smrt“ je ale možné nahradit různými synonymy, napríklad „,osud“, „,bilancováni““, „krok do neznáma“, „odevzdanost“, „odcházení“, „proměna“ atd. Ta ukazují, že smrt je komplexní zážitek a že si s definicemi podle jednotlivých vědeckých disciplín zcela jednoduše nevystačíme (Kuře 2004). Některá synonyma jsou spojená s pozitivními a př́ijemnými zážitky, jako jsou „spánek“, „odpočinek“, „pokoj“, „smířeni“"; další s nepř́ijemnými (nebo pro někoho dokonce negativními) prožitky, jako jsou napríklad „,ztráta“, „,bolest“, „,utrpení“, „trápení“, „strach“, „smutek“, „opuštěni“ a další. Smrt je ale i určitou hranicí mezi životem, který jedinec žije, a něčím, co je za ním, tedy něčím neznámým (,neexistování“), něčím, co je již za hranicí naší zkušenosti. Smrt také život ukončuje.

Smrt jedince se může dělit podle různých přícin: je to podlehnutí nějaké nemoci, nebo smrt stárím (přirozená smrt), smrt způsobená vlastní vinou (sebevražda, sebezabití), smrt v důsledku podmínek neslučitelných se životem (hladem nebo žízní, smrtelný úraz), smrt způsobená jiným člověkem (zabití, vražda, poprava) či smrt způsobená zvířetem či rostlinou (otrava). Stává se, že organismus umírá na kombinaci více př́čin (Rozsypal 2003). Pokud člověk zemře bez předchozích příznaků a př́ícin, označuje se jeho smrt jako „náhlá“.

Z hlediska medicíny můžeme smrt (latinsky exitus) nejčastěji definovat jako psychickou, sociální, fyzickou, klinickou, definitivní nebo mozkovou (Haškovcová 2000). Psychická smrt je naprostou psychickou rezignací, intenzivně prožívanou beznadějí a zoufalstvím, usnadňuje smrt fyzickou. Sociálni smrt je stav, kdy člověk sice žije, ale je neodvratně vyvázán z důležitých sociálních a interpersonálních vztahů. Smrt psychická a sociální často předchází fyzické smrti. Definitivní klinickou smrtí se v praxi chápe neobnovení spontánní činnosti srdce a zástava dechu. S moderními technologiemi v medicíně je ale nyní možné oživit i lidi, jejichž srdce i dech se zastavily. Smrt fyzická je úplná, trvalá a nezvratná ztráta vědomí, 
tedy mozková smrt (Baštecká a kol. 2003). U člověka dochází k nevratným změnám mozku, nastane selhání funkce a zánik center ř́íících krevní oběh a dýchání.

Můžeme také rozlišit dobrou a zlou smrt (Weisman 1972). K dobré smrti dochází v přirozeném prostředí: člověk odchází proto, že je starý, nemocný, a protože již dokončil všechny důležité věci. Má sice přiměřený strach ze ztráty kontroly, ale zachovaný pocit identity, důležité vztahy i snahu o dosažení smysluplných cílů. Zlá smrt znamená pocity utrpení, bolesti, psychické nouze, stresu, sociální izolace a nezájmu o potřeby pacienta. Ještě před sto lety lidé umírali nejčastěji doma, nyní většina lidí umírá v institucích. Problémy institucionalizace smrti jsou profesionalizace, medikalizace, sekularizace a vytěsnění smrti (Hytych 2008). Pro většinu rodin pacienta je ale přesto nepřijatelné, aby pacient umřel sám, proto se poslední dny nevzdalují od jeho lı̊̌̌ka v nemocnici, LDN nebo hospicu. Často se stane, že se odejdou napít nebo na chvilku něco vyř́ídit do města, a právě v té chvíli umírající vydechne naposledy, bez nich, sám. Rodina si potom vyčíá, že ho opustila v nejtěžší chvíli. Příklad ukazuje následující krátká kazuistika.

Medička se už měsíc starala v hospicu o svého těžce nemocného otce: trávila s ním všechny odpoledne a večery, jak jen to bylo možné. Na jeden večer se od něho vzdálila, aby s práteli oslavila svoje narozeniny. Právě ten večer otec zemřel. „Do smrti si to budu vyčitat, " obviňovala se, , ,ale asi patřil k těm, kteři chtèli skonat sami, “ ř́ká smíreně ted", až téměr po dvaceti letech. Dlouho to nemohla pochopit, měla vztek na sebe, na zdravotni systém, samozřejmě na otce, že ,,ji v tom nechal“, a zároven̆ byla smutná, že s ním v poslední chvíli nebyla. Až ted', jako zkušená internistka pochopila, že informace o umírání a smrti by snad měl obdržet každý. Snaži se proto své pacienty a jejich rodiny edukovat a více s nimi o tématu smrti mluvit, pokud projevi hlubši zájem.

Samotný proces umírání můžeme rozdělit do tří fází (fáze 1 a 2 se mohou prolínat): Fáze před umíráním znamená postupné stárnutí organizmu, vyhasínání energie a sil, které je způsobené věkem, onemocněním či stavem spojeným s absencí psychosociálních podnětů. Nemocný může (ale nutně nemusí) trpět vytržením ze sociálního prostředí, již většinou delší dobu nepracuje (je v invalidním či starobním důchodu), sociální sít nemusí být pevná, postupně ztrácí, nebo již ztratil, sociální role a rozvíjí se obavy z opuštěnosti, strach z dalšího průběhu nemoci, strach z léčebných procedur, strach ze zvládání inkontinence, strach ze smrti, strach ze ztráty sebeovládání. Uvědomění si blížící smrti je výzvou k prožívání smyslu života, kvality a také smrtelnosti každé lidské bytosti. Ve fázi umírání bezprostředně hrozí fyzická smrt. Převládá trvalý či dočasný pobyt $\mathrm{v}$ nemocnici, nebo je kombinovaný s pečovatelskou službou či jinými zařízeními (hospic, LDN). Nevyléčitelně nemocný žije pod hrozbou smrti, ke které nakonec dojde. Terminální stadium je vlastně spěním ke smrti, která zasahuje jedince $\mathrm{v}$ celé existenci. Terminální fáze onemocnění je často popisována jako „konec, naplnění, dokončená kniha, prázdno, nicota“ atd. $\mathrm{V}$ této fázi dochází $\mathrm{k}$ zásadní proměně života: dřívější stadium v sobě zahrnovalo určité naděje, $v$ terminálním stadiu životní možnosti jedince klesají, času je málo, budoucnost je pro jedince ztracená a mizející, orientuje se na minulost. Fáze po smrti je období, které začíná smrtí člověka a nese s sebou péči o tělesnou schránku umírajícího a psychické strádání pozůstalých. 


\section{Př́stup ke strachu ze smrti}

Přístup ke smrti můžeme popsat třemi různými způsoby: 1. Neosobni přístup ke smrti znamená, že se smrt netýká nás osobně. Můžeme například číst zprávy o mrtvých a obětech válek, prrírodních katastrof, genocid atd., a to beze strachu, protože naše mysl nám nedovolí takovou smrt připustit jako reálnou. Odmítáme tím i možnost, že by se něco takového mohlo stát nám. 2. Mezilidský přístup ke smrti znamená, že zemře někdo blízký a jedinec změní svůj způsob uvažování o smrti z neosobního na mezilidský. Tomuto př́stupu ke smrti jsou v profesionální rovině denně vystaveni všichni členové paliativního týmu. 3. Osobni př́ístup ke smrti může mít ve vyhraněné formě podobu strachu z vlastní smrti. Vyskytuje se zvýšeně u všech povolání ve zdravotnictví (Wedding a Stuber 2006). Pro lékaře a další zdravotníky mohou být myšlenky na vlastní konečnost zdrcující. Pokud člen paliativního týmu nerozumí sám sobě, smrti a strachu ze smrti, mohou úzkost a strach negativně ovlivnit péči o umírající pacienty.

Očekávat vlastní smrt je obávaná zkušenost nejen pro jednotlivé členy paliativního týmu, ale i pro pacienty. Kde jinde by byl strach ze smrti více viditelný, než u pacientů $\mathrm{s}$ terminálním stupněm onemocnění. Jako synonyma pro strach ze smrti se užívají termíny „úzkost“", „strach“" nebo „hrůza ze smrti“. Např́iklad filozofové hovoří místo strachu ze smrti o uvědomění si „křehkosti bytí“ (Jaspers 1996), o „děsu z nebytí“ (Kierkegaard in Staubrand 2009), o „nemožnosti dalších možností“ (Heidegger 2008), nebo o „ontologické úzkosti“ (Tillich 2004). Psychoanalytik Otto Rank užíval jako synonyma „strach ze smrti“ a „strach ze života“: lidé se mohou bát i života, pokud se život stává př́liš obtížný, bolestivý, hrůzný a vyvolávající úzkost (Lieberman 1993).

Protože se úzkost a strach často užívají ve spojení se smrtí jako synonyma, definujeme dále úzkost, strach, fobii a thanotofobii. Úzkost je nedílnou a životně důležitou součástí života, souvisí s pudem sebezáchovy. Je to nepř́ijemný emoční stav, jehož příčinu není možné definovat. Úzkost, která není omezena na konkrétní vnější okolnosti, je například typickým znakem generalizované úzkostné poruchy. Často je vyjádřena jako obava, že osoba sama, nebo její př́íbuzní, brzy onemocní nebo je postihne jiný zdravotní problém, neštěstí či smrt. Úzkost je doprovázena motorickým napětím a somatickými projevy (pocení, nevolnost, závratě, tachypnoe atd.). Pokud se takový úzkostný pacient setká s neodvratitelnou vlastní smrtí, je nutná pomoc psychoterapeuta.

Strach je přirozená emoční reakce na rozpoznatelné a konkrétní nebezpečí. Má ochranný a informační charakter a trvá pouze po dobu existence ohrožení. Smrt je konkrétní nebezpečí, ale ohrožení při hrozící smrti trvá stále. Strach u pacientů ovlivňuje průběh terminální léčby; často ze strachu ztráty vlastního těla nebo z jiných vedlejších negativních účinků odmítnou podstoupit paliativní chemoterapii nebo operaci. Je nutné také zmínit „memento mori“: neustálé uvědomování si smrti, takže pro samé myšlení na smrt člověk přestává žít, život se mění v očekávání smrti. Pamatování na smrt může být projevem životní zralosti, ale také stavem patologickým.

Specifická fobie je silný a nepřiměřený, chorobný a iracionální strach z konkrétní situace, objektu nebo činnosti vně pacienta, které běžně nejsou nebezpečné, mimo ně nemusí být pacient zvýšeně úzkostný. Postižený si nesmyslný strach plně uvědomuje, ale není schopen ho vlastní vưlí potlačit. Strach je přítomen nejen při vystavení se situaci, ale i při anticipaci 
situace (anticipační úzkost). Nemocný se tedy situacím vyhýbá, nebo je snáší s pocitem hrůzy. Obvyklé fobie týkající se zdraví a nemoci jsou následující: fobie z nemoci (jako je rakovina, AIDS, pohlavní nemoci nebo nemoci z ozáření), fobie z návštěvy lékaře, ze zranění, z operace nebo jiného lékařského diagnosticko-terapeutického zákroku, z pohledu na krev nebo strach z bolesti. Diagnostická kritéria fobie jsou: 1 . Bezdůvodný a trvalý strach ze specifické nemoci, pacient přijímá nejistě zprávy o negativním výsledku somatického vyšetření a i další opětovaná ujištění lékaře o výsledcích a neexistenci choroby; 2 . Strach je manifestován v panických atakách, které směřují do budoucnosti; 3. Předmět strachu se nemění v čase a přesahuje více jak šest měsíců trvání (Fava a kol. 1995).

Thanatofobie je potom chorobný a iracionální strach ze smrti doprovázející často některé psychické poruchy: hypochondrii, panickou poruchu a fobii (MNK 10, 1992; Prašková a Praško 2000). Přesvědčení o brzké smrti (ačkoliv pro ně nejsou žádné objektivní důvody) je spojeno se strachem ze zpráv, které připomínají smrt, jako je např́ílad pohřeb nebo kondolenční dopis. $\mathrm{V}$ pozdějších stádiích může fobická kvalita výše uvedených strachů vyústit v panickou ataku (Kellner 1986). Někdy se thanatofobie může prezentovat jako chronické obavy depresivních pacientů, nebo jako strach ze smrti obsesivních pacientů. Thanatofobie se ale může vyskytovat izolovaně bez jakýchkoliv dalších psychologických symptomů. Diagnostická kritéria thanatofobie jsou: 1 . Pocity přicházející smrti nebo přesvědčení o vlastní smrti, která nastane ve velmi blízké době, ačkoliv pro to neexistuje žádná objektivní medicínská prířina; 2 . Strach je trvalý, pacient se vyhýbá zprávám i situacím, které by mu nějak mohly připomínat smrt (tj. pohřeb, parte, kondolence atd.), vystavení se těmto podnětům vede k okamžité úzkostné reakci; 3 . Vyhýbání se výše uvedeným situacím a zprávám, úzkostné očekávání a stres výrazně ovlivňují jedince $\mathrm{v}$ jeho běžném životě (Fava a kol. 1995, Rafanelli a kol. 2003). Asi osm procent všech onkologických pacientů splňuje kritéria pro thanatofobii (Grassi a kol. 2005).

\section{Strach vztahující se ke smrti}

Pocity spojené s nadcházející a nevyhnutelnou smrtí bychom mohli vhodněji označit jako strach vztahujicí se ke smrti. K pochopení strachu vztahujícího se ke smrti u terminálně nemocných nám nevystačí pouhé definování strachu, úzkosti a thanatofobie ve smyslu specifické fobie (jak jsme uvedli výše). Již jsme definovali, že strach má konkrétní předmět a úzkost je strachem z něčeho nekonkrétního. Strach ze smrti má sice konkrétní předmět (smrt), ale může být vlastně strachem $\mathrm{z}$ něčeho, $\mathrm{s}$ čím člověk neměl sám osobně co do činění, a úzkost spojená se smrtí může být úzkost z toho, že se stane něco, co neznám. R. May, představitel existenciální psychoterapie, chápal úzkost spojenou se smrtí také jako stav strachu bez předmětu, který se nedá pochopit a lokalizovat. Potom ho nelze lidsky ani terapeuticky ovlivnit, a proto je výsledkem jen další bezmoc a úzkost (Kratochvíl 2006). Pokud tedy nejdřive povedeme pacienta k porozumění emocím, tj. strachu a úzkosti, přeměníme strach z něčeho nekonkrétního, čemu pacient nerozumí (strach z něčeho, co neví, co je, z něčeho, s čím nemá žádnou zkušenost), na strach z něčeho konkrétního, umožní to lepší strategie zvládání. Situaci může komplikovat, pokud člen paliativního týmu sám nerozumí strachu ze smrti, sám se vlastní smrti obává, nebo se obává, že smrt postihne jeho pacienty. 
Můžeme ale chápat strach ze smrti u pacientů v terminálním stadiu jako thanatofobii, pokud v terminálním stadiu existují pro blížící se smrt objektivní medicínské příčiny? Jedná se u všech pacientů, kteří mají obavy ze smrti, o nepřiměřený a iracionální strach, nebo je přirozené, že se smrti bojí? Iracionální strach ze smrti jsme definovali jako thanotofobii. Je ale strach ze smrti u terminálně nemocných opravdu iracionální? A co je vlastně přirozený a iracionální strach ze smrti? Dokážeme to odlišit? Odpovědi se můžeme přiblížit tím, pokud rozlišíme smrt jako ztrátu: 1. somatického těla, 2. psychického vlastnictví (ega), 3. materiálního vlastnictví a 4. identity. Pokud jedinec žije v silném vlastnickém modu všech výše uvedených kategorií, musí se smrti opravdu bát (Fromm 2001). Tento strach je možné oslabit sebeujištěním o vazbě $\mathrm{k}$ životu $\mathrm{v}$ jakékoliv fázi života a opětováním lásky druhých. Léčba strachu ze smrti by tedy neměla u terminálně nemocných začínat přípravou pacienta lékařem (psychologem, duchovním) na smrt, ale úsilím snížit vlastnický modus (těla, ega, materiálního vlastnictví a identity), samozrrejmě vše zasazené do individuálního příběhu pacienta. Čím více se jedinec zbaví jakýchkoliv forem vlastnictví, o to slabší bude jeho strach ze smrti, protože nebude mít co ztratit. A to je vlastně práce celoživotní a celospolečenská a netýká se pouze období umírání. Problém je, že žijeme ve společnosti, která je na materiálním vlastnictví velmi silně založena. V neposlední řadě je strach ze smrti možné oslabit pozitivním bilancováním života a jeho naplnění: často se může zdát, že jde o „nic“, „samozřejmosti“, ve skutečnosti jde však o velké skutky nepomíjejícího významu, protože jsou konané z nezištné lásky.

Klademe si tedy otázku, zda pacienti sami dobře rozumí tomu, čeho se na smrti bojí, nebo zda je to pro ně něco neuchopitelného. Jak si smrt vykládají? Co pro ně individuálně smrt znamená? Má strach ze smrti nějaký konkrétní předmět, a pokud ano, jak se u jednotlivých lidí liší? Smrt samozřejmě znepokojuje neodvratností, časovou nevypočitatelností, možnými strastmi spojenými s umíráním a jeho důsledky. Lidé ale mohou strach ze smrti prožívat velmi odlišně a smrt může mít pro ně různý a velmi individuální význam.

Strach ze smrti sytí následující druhy strachů (upraveno dle Broome 1989, Křivohlavý 1994): je to strach z osamění (budu sám v hrobě, bludná duše bez kontaktu s druhými); strach ze ztráty rodiny; strach, že odchod ze světa bude mít negativní důsledky pro lidi, kteří jsou na pacientovi závislí; strach z nedokončené práce; strach z bolesti a jiného somatického utrpění; strach ze ztráty sebekontroly, ovládání těla, závislosti a omezení pohybu; strach z neznámého procesu umírání; strach z pitvy, strach z nahoty, strach z rozřezání těla na kousky, strach z vybrání mozku z hlavy, strach z probrání v hrobě a nemožnosti utéci; strach z toho, co se stane po smrti atd. Strach spojený se smrtí je tedy zřejmě u každého pacienta složen z několika oddělených strachů. Pacient potom nemusí jasně prezentovat, že se „bojí smrti““, ale některých z výše uvedených strachů; velmi často je zastoupen strach z bolesti nebo strach z jiného somatického utrpení. Následující kazuistika popisuje vyjádření strachu ze smrti obavami z bolesti a $\mathrm{z}$ pohybu.

U čtyřricetiletého pacienta byla před rokem zjištěna „, z čistého zdravi“ “ rakovina boční stěny močového měchýre. Prodélal urostomii, exenteraci malé pánve, trpěl postradiačními kolitidami, atonii a bolestmi. Pacient vyžadoval od lékaře i ostatních zdravotníků čas, přitom byl hostilní, abulický, choval se výrazně bolestínsky, litoval se. Subjektivně popisoval, že byl vždy úspěšný, měl dobré společenské postavení, dům, auto, zvládl rozvod i druhé manželství... 
a ted” tohle, ,proč on? “. V této době již nepracoval a přicházel na konzultace vždy s manželkou, nemohl sám ř́dit. Stěžoval si na nechutenství, neustálé snižování váhy, strach z bolestí a strach z pohybu (proto raději polehával a nadužival analgetika), na nespavost, zhoršeni nálady, izolaci. Bolesti a jejich intenzitu ovlivňovaly tendence k černobílému vidéní problémù (, když mě to bolí, je to špatné, nemoc prograduje“) a anticipace problémů (,, když budu chodit, bude mě to bolet, raději zůstanu v posteli, ani se nehnu“). Postupně zůstával více a více $v$ posteli, také v ní jedl, s nikým se nesetkával, cítil se slabý $i$ na to, aby sešel v domě dolì $k$ rodinè. Strach z bolestí tak vedl $k$ výrazné pasivitě a depresi. Nemluvil o strachu ze smrti, ten byl vyjádřen strachem z bolesti a strachem z fyzické aktivity. Pro to, aby se cítil lépe, chtěl být „zcela bez bolestí a vyléčený“. Na základě terapie svoji zakázku přeformuloval na „,chci zvládat strach z bolesti, ale také strach z pohybu “. Po racionální analgetické terapii, edukaci o naduživání analgetik, lepším zvládnutí strachu z bolesti a pohybu byl pacient schopen udržovat sestavený denní režim, zmírnil se pocit osamělosti a izolovanosti, lépe dokázal zvládat bolest i kognitivně, mírně se snížila deprese a přijatelněji akceptoval následujici paliativni chemoterapii.

Podle časového průběhu můžeme rozlišit tři základní druhy strachu ze smrti: 1. samotnou „událost“ umírání; 2. to, co přijde po smrti; a 3. ukončení bytí (Yalom 2005). V klinické praxi většinou členové paliativního týmu věnují pozornost strachu ze smrti, který se týká samotné události umírání. Léčba pacientů v terminální fázi ale často přivede členy paliativního týmu do oblasti mimo exaktnost a racionálnost, tedy do oblasti toho, co je po smrti a ukončení bytí. Pacienti se sami smrti bojí, zároveň uvažují nad hodnotou života a ke své situaci zaujímají racionální i neracionální, neexaktní postoj. Pacient tak může zaměřit lékaře, sestry, psychologa, sociálního i duchovního pracovníka v paliativním týmu ke spirituálním a existenciálním úvahám ve formě následujících (a mnoho dalších) otázek: Existuje život po smrti?, Co je vlastně po smrti?, Co znamená smrt?, Co znamená ukončení bytí v tomto světě?, Jaký má smrt význam?, Jaký má význam život s nemocí, bolestí a bezmocí? Pokud pacient projeví zájem, může s ním člen paliativního týmu prozkoumávat výše uvedené otázky týkající se hodnoty života, smrti a plnohodnotně tak pacienta provázet procesem umírání.

Jedna z nejvíce traumatizujících zkušeností pro pacienta, který se bojí smrti, je, že pro něho lékař už nemůže ,nic udělat““ (i když to ve verbální komunikaci nebylo vyřčeno). Často si to pacient myslí, protože téma smrti a umírání je $\mathrm{v}$ komunikaci s lékařem tabu (Baider a Wein 2001). Tabuizace smrti př́mo ovlivňuje pacientův strach ze smrti a pocity kontroly. Následující kazuistika popisuje tabuizaci smrti u závažně nemocné pacientky, která sice nebyla onkologicky nemocná, ale neměla naději na vyléčení a umírala.

Mladá žena ležela na jednotce intenzivní péče neurologické kliniky s těžkou herpetickou encefalitidou. Poškození mozku bylo tak závažné, že prognóza přežití byla minimální. Ošetřujici lékařka byla žena, v jejižz rodině bylo téma smrti v komunikaci tabu, protože prvni tři děti matce zemřely. I přes to, že dívka témata smrti a umírání lékařce nabizela, nedostalo se jí na toto téma žádné adekvátní komunikace. Měla tak až do smrti intenzivní pocit, že už pro ni lékařka nechce a nemůže nic udělat. 


\section{Akceptace hrozící smrti}

Úroveň uvědomění a připravenosti nastupující smrti bude u terminálně nemocných různá podle toho, jak je pacient ochotný akceptovat situaci, ve které se nachází, nebo naopak nakolik má tendenci ji popírat. Lidé zvládají hrozící smrt rưzně: někteří se ji snaží popřít; jiní se snaží získat o nemoci tolik informací, jak je to jen možné, aby mohli ovlivnit vlastní zdravotní situaci, a jen velmi málo lidí vlastní smrt absolutně akceptuje (nebo absolutně popírá, často dochází $\mathrm{k}$ ambivalentnímu vztahu). I akceptující jedinec občas popírá situaci, ve které se nachází, ale to je přirozené: nemůže myslet na vlastní smrt po celou dobu. Zvládání a přijetí vlastní smrti je spojeno s individuálními podmínkami somatické nemoci, osobnostními, kulturními a sociálně ekonomickými faktory, které popisuje blíže Př́loha 1 . Byly vypracovány různé typologie zvládání a přijímání smrti a vyrovnávání se s ní, přesto je každý člověk jedinečná bytost, která žije i zemře jedinečným způsobem. Se smrtí se vyrovnává každý jedinec individuálně.

Model přijmutí či nepřijmutí smrti souvisí s pochopením vlastní zkušenosti se smrtí. Individuální reakce umírajícího na neodkladnou smrt je vhodné vztahovat $\mathrm{k}$ jeho: 1. minulým zkušenostem a reakcím na ztráty, 2. zvládacím strategiím užitým v minulosti a 3. specifickým podmínkám konkrétního terminálního onemocnění. Proto můžeme očekávat různé emoční reakce a zvládací strategie u jednotlivých umírajících: někteří bojují, jiní maximálně kontrolují situaci, ve které se nacházejí, jiní jsou pasivní a akceptující, jiní lpí na nezávislosti, další se lehce vzdávají, někteří dosahují více pozitivní přijetí (Hinton 1984).

Z časového hlediska můžeme rozlišit i přijetí tzv. ,jisté smrti“" v neznámý čas u terminálního onemocnění, nebo tzv. „nejisté smrti“" s nejistým koncem u chronického onemocnění, nebo ,jisté smrti“ v určitý čas v důsledku nehody či náhody. Samozřejmě, že přičinou problémů s přijetím je „nejistota smrti“ u závažných chronických onemocnění, stejně tak načasování ,jisté smrti“ u terminálně nemocných. Nejistota je tak jednou z výzev, se kterou se terminálně nemocní musí vyrovnat. S problémem akceptace či popření smrti souvisí otázka, zda lidé vůbec chtějí o vlastní smrti vědět (a v jakém rozsahu) a jak by s touto informací měl lékař eticky pracovat (Raudenská a Javưrková 2010). Má pacient právo vždy na plnou informaci, pokud se ptá, kdy zemře? Je milosrdná lež (tzv. pia fraus) sdělením jen části pravdy? A jak pozná lékař, že by pacientovi plná informace ubližila? Nabízíme dvě krátké kazuistiky ilustrující výše uvedenou problematiku.

Mladá osmnáctiletá pacientka ležela na JIP s tracheostomií, na ventilátoru, pro akutní dekompenzaci. Před dvěma lety jí byla provedena částečná resekce nádoru plic. Po kompenzaci dýchání byla neklidná, plačtivá, verbalizuje strach ze smrti, ptá se, co s ní je, o nádorové diagnóze není informována. Rodina sděluje, že lékař před dvěma lety řekl infaustní prognózu jen rodičùm, děvče o ní neví.

Sedmačtyřricetileté pacientce, vysokoškolsky vzdělané sestře s nádorem žaludku, se vůbec nelibilo, že ošetřujicí lékar̆ na její otázku, zda má rakovinu a kdy zemře, odpovédèl vyhýbavě. Nedozvěděla se, co chtěla slyšet. Domáhala se "pravdy" o zdravotním stavu, protože si chtěla zařídit všechny právní záležitosti, včetně dědictví. Měla strach, že zemře a jeji dům a automobil zdědí bývalý manžel a ne její dvě děti. Přesto až do své smrti od lékaře odpověd' na svou otázku nikdy neuslyšela. 
Při zkoumání reakcí na hrozící smrt jsme si kladli následující otázky: Je strach ze smrti strachem pouze lidí starých a terminálně nebo jinak závažně nemocných? Má strach ze smrti každý? Prostupuje fakt, že jsme spojeni se smrtí, celým naším životem? Narůstá intenzita a vědomí strachu ze smrti tím víc, čím jsme blíže ke stáří a nemoci? Chtějí vůbec lidé vědět zda umírají, či ne? Zajímalo nás, zda se odpovědi budou lišit u: 1. zdravých respondentů, 2. terminálně nemocných a 3 . lékařù pracujících $\mathrm{s}$ terminálně nemocnými.

Polovina zdravých respondentů byla přesvědčena o tom, že by se mělo pacientovi říci, že umírá. Tento názor ale převažoval u mladších respondentů na úkor starších. Sedmdesát procent respondentů by chtělo osobně dostat informaci, že umírají, ale s vyšším věkem se toto přání snižovalo (Broome 1989). Také kultura, životní zkušenost, osobnost a etnická př́islušnost mohou ovlivňovat individuální postoje týkající se informací o smrti a umírání. Názor na to, kolik a jaké informace by měl pacient od lékaře dostat, se liší např́íklad u různých etnik v USA. Nepříznivé informace by chtělo dostat $88 \%$ Afroameričanů, $87 \%$ Američanů evropského původu, $65 \%$ Američanů mexického původu, $35 \%$ Američanů korejského původu a nikdo z indiánů kmene Navajo. Ti věří, že jazyk vytváří realitu a může ovlivňovat události: vyřčená negativní diagnóza a prognóza se naplní (Praško a Horáček 2007).

$\mathrm{S}$ ústupem náboženství v Evropě se diagnóza a prognóza pacientovi neříkala a pacient se udržoval v naději na vyléčení a přežití (tzv. „svatá lež“). Od 70. let 20. století se v USA objevily trendy $\mathrm{k}$ větší otevřenosti o prognóze a fatalitě onemocnění. Přesto americké studie ze 70. a konce 80 . let 20 . století ukazují, že 80-90\% terminálně nemocných pacientů ví, že umírá a přeje si o tom mluvit, ale 60-90 \% lékařuo o smrti s pacienty nemluví (Annas 1974, Broome 1989). Lidé si zřejmě uvědomují, že umírají, navzdory nedostatku otevřených informací tak, jak nemoc prograduje. Otázka, kterou si klademe, je, zda lékaři opravdu nechtěli, nebo váhali, či nebyli vyškoleni o umírání a smrti s pacienty mluvit.

Lékaři jsou v současné době aktivováni $\mathrm{k}$ následujícímu postoji: pacient by měl být pravdivě informován o prognóze $\mathrm{v}$ rozsahu jeho přání a měl by se potom aktivně podílet na rozhodování o léčbě. Podle zeměpisné př́ílušnosti existují rozdílné názory lékařů na to, zda pacient chce vědět, že umírá, nebo nechce. Například lékaři v Kanadě se domnívají, že asi polovina pacientů chce vědět, že umírá, lékaři v Jižní Americe si myslí, že je to pouze pětina, a lékaři v Evropě odhadují, že je to jedna třetina pacientů. $V$ př́ípadě otázky, co si lékař myslí o tom, jak chce být informována rodina umírajícího, jsou výsledky podobné. Většina lékařu se ale shodla, že by osobně informaci o umírání a blížící se smrti dostat chtěla, pokud by na místě umírajícího byli oni sami (Bauera a kol. 2000).

Diagnózu i závažné informace o stavu sděluje $\mathrm{v}$ paliativním týmu vždy a jen lékar̆. Lékařova ochota sdělit pacientovi, že umírá, může být ovlivněna i fyzickou, psychickou či sociální přitažlivostí pacienta. Mladší, atraktivní, přitažliví pacienti a ti, kteří měli důležité společenské postavení, dostali více informací, než jiní (Lasagna 1970). Váhání a neochota lékaře potvrdit pacientovi, že mu hrozí smrt, je v kontrastu s pacientovou připraveností. Postoj lékaře ke smrti a umírání je tak jedním z možných základních zdrojů pacientova popření nebo akceptace. Lékař může pacienta povzbuzovat v popření smrti, protože to vyvolává méně úzkosti, než otevřené rozhovory o smrti. Další faktory, které brání lékaři otevřeně komunikovat s pacientem o hrozící smrti, jsou následující: pacient trpí bolestí, která není dobře monitorována, nebo není monitorována vůbec, nebo pacient není schopen se 
na rozhovor s lékařem soustředit. Pacient také může mít strach, že mu lékař neporozumí, pokud se před ním zmíní o strachu ze smrti a umírání. Mýtus je zakořeněný i mezi rolemi zdravotnického personálu: lékař je ten, kdo operuje a dělá jiné „zázraky“, sestry si s pacientem ,jenom“ povídají. Pacient potom může mít strach vyjádřit před lékařem emoce, aby ho tím neobtěžoval. Někteří pacienti například zachovávají mlčení o smrti, aby „nezranili“ lékaře nebo vlastní rodinu. Až jedna třetina terminálně nemocných nemluví se svými partnery o skutečnosti, že umírají (Wilson 1989). Strach vyjádřit své vlastní emoce nebo být s nimi konfrontován může mít i lékař. Jeho strach z vlastní smrti může blokovat připravenost mluvit o tomto tématu s pacienty.

\section{Závěr}

Jsme schopni zažít smrt druhého a můžeme si tak uvědomit to, co jsme si předtím neuvědomovali, tj. vlastní smrtelnost. Tím získáváme nové komplexní poznání. To je závažný fakt pro celý paliativní tým. Protože umírání je problémem nejen bio-psycho-sociálně-spirituálním, právním, filozofickým i ekonomickým, ale především humánním: na celý paliativní tým je kladen velký nárok. Je důležité, aby každý člen paliativního týmu pečujícího o umírající rozuměl nejdříve sám sobě a také psychologickým problémům spojeným se smrtí a umíráním. Proces umírání je smysluplný pouze tehdy, pokud je pacient tělesně, psychologicky, sociálně, spirituálně a emocionálně podporován celým zdravotnickým týmem, rodinou a přáteli.

Základem péče o umírající tedy nejsou jen medicínské znalosti, soucit, pochopení prožívané bolesti, utrpení a strachu ze smrti, ale vždy i individuální př́iběh každého jedince. I když bude pregraduální vzdělávání jednotlivých členů paliativního týmu odlišné (lékařská fakulta vzdělává lékaře a zdravotní sestry, filozofická fakulta klinické psychology a sociální pracovníky, teologická fakulta duchovní), přesto by postgraduální vzdělávání v paliativní péči mělo poskytnout vzdělání v porozumění sebe sama a vlastnímu vztahu k celku světa. Takové vzdělání reflektuje i formování společnosti a kultury, která produkuje ochotu, př́izeň, důvěru, pochopení, respekt a celostní péči o umírajícího člověka.

\section{Literatura}

ANNAS, George. Rights of the Terminally Ill Patients. Journal of Nursing Administation, 1974, č. 4, s. 403. ISSN 0002-0443.

BAIDER, Lea; WEIN, Simon. Reality and Fugues in Physicians Facing Death: Confrontation, Coping, and Adaptation at the Bedside. Critical Reviews in Oncology/Hematology, 2001, roč. 40, č. 2, s. 97-103. ISSN: 1040-8428.

BAŠTECKÁ, Bohumila a kol. Klinická psychologie v praxi. Praha: Portál, 2003. ISBN: 80-7178-735-3.

BAUERA, Eduardo; NEUMANN, Catherine M.; MAZZOCATO, Claudia; STIEFEL, Fritz; SALA Raul. Attitudes and Beliefs of Palliative Care Physicians Regarding Communication with Terminally Ill Cancer Patiens. Palliative Medicine, 2000, roč. 14, č. 4, s. 287-298. ISSN: 0269-2136.

BROOME, Annabel K. (ed.). Health Psychology. London: Chapman and Hall, 1989. 427 s. ISBN 0-412-33200-0. 
Jaroslava Raudenská, Alena Javưrková: Strach ze smrti u dospělých umírajících pacientů

FAVA, Giovanni A.; FREYBERGER, Harald J.; BECH, Per; CHRISTODOULOU, George; SENSKY, Tom; THEORELL, Töres; WISE, Thomas N. Diagnostic Criteria for Use in Psychosomatic Research. Psychother Psychosom, 1995, č. 63, s. 1-8. ISSN 0033-3190.

FROMM, Erich. Mit, nebo být? Praha: Aurora, 2001. 242 s. ISBN 80-7299-036-5.

GRASSI, Luigi; SABATO, Silvana; ROSSI, Elena; BIANCOSINO, Bruno; MARMAI, Luciana. Use of the Diagnostic Criteria for Psychosomatic Research in Oncology. Psychother Psychosom, 2005, č. 74, s. 100-107. ISSN 0033-3190.

HAŠKOVCOVÁ, Helena. Manuálek o etice: České ošetřovatelství. Brno: IDV PZ, 2000. 46 s. ISBN 80-7013-310-4.

HEIDEGGER, Martin. Bytí a čas. Praha: Oikoymenh, 2008. 487 s. ISBN 978-80-7298-048-3.

HINTON, John M. Coping with Terminal Illness. In: FITZPATRICK R.; HINTON J. M.; NEWMAN, S. a kol. (eds.) The Experience of Illness. London: Tavistock Publications, 1984, s. 227-245. ISBN: 042278530X.

HYTYCH, Roman. Smrt a nesmrtelnost: Sociální reprezentace smrti. Praha: Triton, 2008. 227 s. ISBN: 978-80-7387-092-8.

JASPERS, Karl. Úvod do filosofie. Praha: Oikoymenh, 1996. 119 s. ISBN: 80-86005-05-4.

KELLNER, Robert. Somatization and Hypochondriasis. New York: Praeger, 1986. 401 s. ISBN 0-03-069528-7.

KNIGHT, Sara J. Oncology and Hematology. In: CAMIC P.; KNIGHT S. J. (eds.) Clinical Handbook of Health Psychology. Cambridge: Hogrefe \& Huber, 2004, s. 233-261. ISBN 0889372608.

KOZÁK, Jiří. Léčba bolesti v ČR - chronická bolest a trendy v invazivních postupech. Remedia, 2002, č. 6, s. 364-369. ISSN 0862-8947.

KRATOCHVÍL, Stanislav. Základy psychoterapie. Praha: Portál, 2006. 383 s. ISBN 80-7169-121-6.

KŘIVOHLAVÝ, Jaro. Jak zvládat stres. Praha: Grada, 1994. 190 s. ISBN: 80-7169-121-6.

KUŘE, Josef. Filozofické poznámky k legislativě paliativní péče. Zdravotnické právo v praxi, 2004, č. 4, s. 80-82. ISSN 1213-0508.

LASAGNA, Lea. Physicians' Behaviour Towards the Dying Patiens. In: BRIM O. G.; FREEMAN H.; LEVINE S. (eds.) The Dying Patient. New York: Russell Sage Foundation, 1970, s. 67-83. ISBN: 978-0-87154-155-0.

LIEBERMAN, James E. Acts of Will: The Life and Work of Otto Rank. Amherst: U. Massachusetts Press, 1993. 485 s. ISBN 0029190207.

Mezinárodní klasifikace nemocí (MKN, 10. revize). Praha: Psychiatrické Centrum, 1992. 282 s. ISBN 80-85121-37-9.

PRAŠKO, Ján; HORÁČEK, Jiří. Umírající pacient. In: HERMAN E.; PRAŠKO J.; SEIFERTOVÁ D. (eds.) Konziliárni psychiatrie. Praha: Galén, 2007, s. 221-233. ISBN Medical Tribune CZ 978-80903708-9-0.

PRAŠKOVÁ, Hana; PRAŠKO, Ján. Úzkostné a fobické poruchy. Malá psychiatrie pro praktické lékaře. Praha: Galén, 2000. 102 s. ISBN 80-7262-039-8.

RAFANELLI, Chiara; RONCUZZI, Renzo; FINOS, Livio; TOSSANI, Eliana; TOMBA, Elena; MANGELLI, Lara; URBINATI, Stefano; PINELLI, Giuseppe; FAVA, Giovanni A. Psychological Assessment in Cardiac Rehabilitation. Psychother Psychosom, 2003, č. 72, s. 343-349. ISSN 0033-3190.

RAUDENSKÁ, Jaroslava; JAVU゚RKOVÁ, Alena. Možnosti kognitivně-behaviorální terapie v léčbě somatických onemocnění (model chronické bolesti u pacientů s kognitivními poruchami). Bolest, 2002, roč. 5, č. 3, s. 164-167. ISSN 1212-0634.

RAUDENSKÁ, Jaroslava; JAVŮRKOVÁ Alena. Některé etické úvahy, dilemata a podněty algeziologické péče o pacienta s chronickou nenádorovou bolestí. Bolest, 2010, roč. 13, č. 4, s. 172-180. ISSN 1212-6861.

ROZSYPAL, Stanislav. Nový přehled biologie. Praha: Scientia, 2003, s. 458. ISBN 80-7183-268-5. 
STAUBRAND, Jens. Søren Kierkegaard's Illness and Death. Kodaň: Søren Kierkegaard Kulturproduktion, 2009. 128 s. ISBN 978-87-92259-92-9.

TILLICH, Paul. Odvaha být. Praha: CDK, 2004. 138 s. ISBN-10: 80-7325-016-0.

WEISMAN, Avery D. On Dying and Denying. New York: Behavioral Publications, 1972. 247 s. ISBN: 0877050686.

WEDDING, Danny; STUBER, Margaret L. Behavior \& Medicine. Cambridge: Hogrefe \& Huber, 2006. 389 s. ISBN 0-88937-305-1.

WILSON, Christine. Terminal Care: Using Psychological Skills with the Terminally Ill. In: BROOME, A. K. (ed.) Health Psychology. London: Chapman and Hall, 1989, s. 476-493. ISBN 0-412-33200-0.

YALOM, Irvin. Existenciální psychoterapie. Praha: Portál, 2005. 520 s. ISBN 80-7367-147-6.

\section{Př́loha 1}

Faktory ovlivňující zvládání, přijetí a adaptaci na hrozící smrt (Knight 2004)

1. Medicínské faktory:

- typ nemoci, průběh, prognóza nemoci, příznaky (například bolest, únava, dušnost...);

- dovednosti a zkušenosti personálu v paliativní a suportivní péči;

- místo, kde je terminální péče prováděna (domov, nemocnice, hospic, domov důchodců, LDN).

2. Osobnostní faktory:

- premorbidní psychické potíže;

- předchozí zkušenosti se ztrátou, stresem a smrtí;

- premorbidní schopnosti adaptace;

- zvládací strategie užité v minulosti.

3. Kulturní, společenské, spirituální postoje a socioekonomické zdroje:

- přítomnost podpory v rodině, jiná sociální podpora;

- vztah zdravotnického prostředí ke smrti a umírání;

- postoje společnosti k terminálnímu stadiu nemoci a vztah ke smrti.

\section{Autorky}

Jaroslava Raudenská vystudovala jednooborovou psychologii na Filozofické fakultě Univerzity Karlovy v Praze. Je klinická psycholožka a kognitivně-behaviorální terapeutka, pracuje jako vedoucí Oddělení klinické psychologie ve Fakultní nemocnici v Motole v Praze. Zabývá se psychologickou diagnostikou a psychoterapií u pacientů s chronickou nádorovou i nenádorovou bolestí. Přednáší lékařskou a zdravotnickou psychologii a psychologii bolesti na 2. LF UK Praha a v postgraduálním vzdělávání lékařù - algeziologů.

Kontakt: jaroslava.raudenska@fnmotol.cz

Alena Javiorková vystudovala jednooborovou psychologii na FF UK v Praze. Je klinická neuropsycholožka a kognitivně-behaviorální terapeutka. Pracuje jako vedoucí Oddělení klinické psychologie ve Fakultní nemocnici Královské Vinohrady v Praze. Specializuje se na neuro- 
Jaroslava Raudenská, Alena Javưrková: Strach ze smrti u dospělých umírajících pacientů

psychologické testování kognitivních funkcí. Ve spolupráci s FN Motol provádí u pacientů $\mathrm{s}$ epilepsií předoperační vyšetření kognitivních schopností včetně Wada testu. V psychoterapii se specializuje na zvládání chronické nemoci. Přednáší neuropsychologii v postgraduálním vzdělávání klinických psychologů a lékařů.

Kontakt: javurko@fnkv.cz 